UDK 630*44:582.632.2(234 Motajica)

582.632.2:582.728.4(234 Motajica)

\title{
SUŠENJE HRASTA KITNJAKA [QUERCUS PETRAEA (MATTUSCHKA) \\ LIEBLEIN] I POJAVA IMELE LORANTHUS EUROPAEUS JACQ. NA PLANINI MOTAJICI
}

\section{Decline of sessile oak [Quercus petraea (Mattuschka) Lieblein] and occurrence of the mistletoe Loranthus europaeus Jacq. on mountain Motajica}

\author{
Neđo Ilić ${ }^{1}$
}

\begin{abstract}
This paper is dealing with decline of the sessile oak [Quercus petraea (Mattuschka) Lieblein] in Bosnia and Herzegovina that is increasing recent years. Attention is paid to the mistletoe Loranthus europeus, which is common in our oak stands. Recent investigation on the occurrence of the mistletoe on the mountain Motajica underlines it as a new threat to the sustainable management with these forests. Thus, oak decline caused by other factors (e.g. climatic changes) might go from bad to worse. Intensity of the infested trees at studied plots take out from $11,8 \%$ to $77,8 \%$ within dbh class $20-30 \mathrm{~cm}$ and over $70 \mathrm{~cm}$ respectively. It is concluded that lack of a proper forest management was one of factors responsible for the mistletoe spread.
\end{abstract}

Key words: Loranthus europeus, mistletoe, Quercus petraea, Sessile oak.

\section{Izvod}

U ovom radu govori se o pojavi sušenja hrasta kitnjaka [Quercus petraea (Mattuschka) Lieblein] u Bosni i Hercegovini, koja se posljednjih godina sve više širi. Posebna pažnja je data žutoj imeli Loranthus europeus koja je inače vrlo česta u našim šumama hrasta. Posljednja istraživanja pojave imele na planini Motajici upozoravaju da je ovo nova prijetnja potrajnom gazdovanju ovim šumama. Na ovaj način sušenje hrasta koje prouzrokuju drugi faktori okoline (na primjer, klimatske promjene), može se dalje pogoršavati. Intenzitet imelom napadnutih stabala na eksperimentalnoj plohi iznosio je 11,8\% u debljinskoj klasi 20-30 cm, a čak 77,8\% u debljinskim klasama iznad $70 \mathrm{~cm}$. U zaključku se ističe da je nedostatak odgovarajućih gazdinskih mjera bio jedan od faktora koji je uticao na širenje imele.

Kliučne riječi: Imela, kitnjak, Loranthus europaeus.

${ }^{1}$ JP "Šume Republike Srpske" 


\section{Predgovor}

Šume hrasta kitnjaka [Quercus petraea (Mattuschka) Lieblein] u Bosni i Hercegovini, i u Evropi uopšte, su destabilizovane, a u nekim područjima zabilježeno je i njihovo masovno sušenje. Pojava se najčešće dovodi u vezu sa promjenom klime (česte i dugotrajne suše, kasni proljetni mrazovi), sistemom gazdovanja, genotipom, starošću, zagađenjem okoline, bolestima (pepelnica, traheomikoze), primarnim insektima (defolijatori), edafskim i drugim predisponirajućim faktorima okoline koji fiziološki slabe stabla do mjere da ih napadaju i sekundarni biotički agensi. U dosadašnjim istraživanjima pojave sušenja hrasta u Evropi, međutim, ne ističe se moguća uloga žute imele Loranthus europaeus. Naša istraživanja o pojavi ove imele na Motajici upućuju na zaključak da ova parazitska cvjetnica može da ima važnu ulogu u ovom procesu.

Na području Motajice hrast kitnjak je u prošlosti gradio vrlo kvalitetne sastojine prvog boniteta i dobro se podmlađivao. Nažalost, ove šume je napala imela koja sve više prijeti da, sama ili zajedno sa drugim štetnim agensima, destabilizuje ove sastojine, što je bio razlog istraživanja ove pojave.

\section{UVOD - Introduction}

Kitnjak raste u Evropi i Maloj Aziji. Prema MAtıću i saradnicima (1971) šume hrasta kitnjaka u Bosni i Hercegovini zauzimaju oko 300.000 ha (visoke oko 102.000 ha i izdanačke oko 198.000), od kojih se na boljim staništima nalazi oko 130.000 ha (visoke 43.000 ha, izdanačke 87.000 ha). Naše kvalitetne šume kitnjaka najrasprostranjenije su u Bosanskoj Posavini, u donjim tokovima rijeke Une, Vrbasa, Bosne i Drine, ali su one i ovdje, nažalost, destabilizovane, a na nekim lokalitetima i propadaju.

Sušenje hrastovih šuma nije nova pojava u Evropi i pominje se još krajem 19. i početkom 20. vijeka. Posljednji talas sušenja ovih šuma počeo je 1980. godine i do kraja 20. vijeka zabilježen je u gotovo cijeloj Evropi. Istraživači se slažu u ocjeni da su simptomi sindroma sušenja hrasta manje-više isti u cijelom svijetu. STEINER (1998) ističe da propadanje hrasta nije rezultat bilo kojeg pojedinačnog agensa, nego je to bolest na čiji tok utiču različiti faktori okoline i interakcija među njima. Zavisno od lokaliteta bilo koji od ovih faktora može imati odlučujuću ulogu. Među abiotičkim faktorima ovaj autor ističe sušu i mraz kao najčešće, ali navodi da i drugi faktori (saturirano zemljište i njegova fizička i hemijska svojstva, zagađenje okoline, nagib terena, mehanička oštećenja stabala) mogu biti involvirani. Među biotičkim faktorima, prema ovom autoru, značajnu ulogu mogu imati: vrsta hrasta i genotip, različiti insekti defolijatori (naprimjer Lymantria dispar), insekti drvenari (naročito Agrilus vrste) i brojni patogeni slabosti (naročito Armillaria spp.).

Općenito se može reći da većina istraživača ističe klimu (naročito sušu) kao odlučujuću u procesu sušenja hrasta, tako što predisponira stabla negativnom uticaju biotičkih faktora, i da nijedan pojedinačni patogen niti insekt ne može prouzrokovati 
sušenje većih razmjera. Prihvata se mišljenje njemačkog šumara Falcka (SIWECKI \& UFNALSKI, 1998) kao najvjerovatnije objašnjene ove kompleksne pojave. On opisuje dvije faze procesa sušenja: (1) faza slabljenja i (2) faza ireverzibilnog sušenja. Prva faza, zavisno od lokalnih uslova staništa, može biti posljedica kompleksa interakcijskih odnosa suše, smanjenja nivoa podzemne vode, napada insekata (uglavnom foliofaga), gljivičnih bolesti, slabljenja aktivnosti mikoriznih gljiva, grešaka u gospodarenju u prošlosti i, možda, uticaja polutanata. Druga faza se odvija relativno brzo i uzrokovana je aktivnostima patogenih gljiva koje napadaju razne organe vaskularnog sistema i korijena, što je onda konačna faza toka bolesti.

Interesantno je napomenuti da se pri dosadašnjem tumačenju uzroka masovnog sušenja hrastova u Evropi ne pominje uloga imele L. europaeus, što može biti u vezi sa zanemarivo slabim intenzitetom njene pojave u prošlosti. Malobrojna su istraživanja o uticaju ove imele na zdravstvenu sliku šuma hrasta u $\mathrm{BiH}$ i pretežno su opservacijskog karaktera (TREŠTIĆ i saradnici, 2006).

\subsection{Loranthus europaeus Jacq. - hrastova imela}

L. europaeus je rasprostranjen u cijeloj Evropi. U nas je vrlo čest na hrastovima. IDŽOJTIĆ i saradnici (2005) navode da se žuta imela, pored hrastova: kitnjaka (Quercus petraea), lužnjaka ( $Q$. robur), cera ( $Q$. cerris), medunca ( $Q$. pubescens), sladuna ( $Q$. frainetto), crvenog hrasta (Q. rubra L.), javlja još i na bukvi (Fagus silvatica L.), pitomom kestenu (Castanea sativa Mill.) i grabu (Carpinus betulus L.). KRÜSSMANN (1977) kao domaćina žute imele navodi i maslinu (Olea europaea L.).

\section{PODRUČJE ISTRAŽIVANJA - Research area}

Istraživačko područje je planina Motajica. Gazdovanje ovim šumama u prošlosti baziralo je na različitim principima. Struktura sastojine pokazuje da je ovdje nekada primjenjivana oplodna sječa koja je kasnije napuštena i formirane su manje ili više dvospratne sastojine. U gornjem spratu nalaze se stabla starosti do 140 godina (prečnika iznad $30 \mathrm{~cm}$ ), a u donjem podmladak koji mjestimično prelazi u letvenjake. Zahvaljujući dobrim stanišnim uslovima podmlađivanje je dobro.

Zašto je izmjenjen metod gazdovanja šumama hrasta na ovom području nije poznato, ali je očigledno da to nije učinjeno na naučnoj osnovi. Pri određivanju novog, drugačijeg sistema gazdovanja ovim šumama nisu uvažavana iskustva iz prošlosti koja se odnose na proces masovnog sušenja šuma hrasta u Evropi i moguće štetne agense (prateće bolesti i štetnici, promjena klime, zagađenje okoline i dr.), koji desetabiliziraju ove šume, mijenjaju njihov biodiverzitet i konačno prouzrokuju njihovo sušenje. Ovakav odnos prema gazdovanju nalazi se dijelom i u legislativi. Tako, naprimjer, zaražena stabla bez obzira o kojem prouzrokovaču se radi, ne smiju se posjeći sve dok potpuno ne ostanu bez lista. Dakle, prema zakonskoj regulativi sanitarne sječe se mogu primjenjivati samo ako se radi o suhim stablima. Ovakav 
odnos prema održavanju higijene u šumama nema stručni oslonac i često se laički tumači drugim razlozima.

Radi potpunijeg razumijevanja procesa sušenja, što je i zadatak ovog rada, analizirane su klimatske karakteristike ovog područja u bliskoj prošlosti.

\subsection{Klimatske karakteristike područja}

Analizirane su klimatske karakteristike za meteorološke stanice Prnjavor i Srbac, mjesta u podnožju planine Motajice. Prema ovim podacima klima ovog područja u prošlosti je bila umjerena (temperaturni režim povoljan, prelaz ljeta u zimu blag, vlažnost vazduha relativno dobra, padavine ravnomjerno raspoređene tokom godine i najobilnije u vegetacionom periodu). Ovakvi klimatski uslovi pogodovali su prirodnoj obnovi šuma i razumljivo je da nisu mogli biti bitan faktor okoline koji bi mogao destabilizovati šume kitnjaka i tako uticati na sušenje stabala.

Tragajući za uzrocima sušenja kitnjaka na Motajici danas, analizirani su i novi podaci o klimi ovog područja, očekujući da bi eventualne promjene mogle uticati na ovaj proces. Korišteni su podaci Meteorološke stanice u Srpcu (grad na obroncima Motajice) za period 2000.-2007. g., na osnovu kojih je izračunat indeks suše prema De Martonneovoj formuli (tabela 1).

$$
I=12 h:(t+10)
$$

$I=$ indeks suše

$h=$ suma padavina odgovarajućeg mjeseca

$t=$ srednja temperatura vazduha odgovarajućeg mjeseca

Tabela 1. Indeks suše za Srbac

Table 1. Drought index

\begin{tabular}{|c|c|c|c|c|c|c|c|c|c|c|c|c|}
\hline \multirow{2}{*}{ Godina } & \multicolumn{10}{|c|}{ Mjeseci } \\
\cline { 2 - 12 } & I & II & III & IV & V & VI & VII & VIII & IX & X & XI & XII \\
\hline 2000 & 47 & 28 & 41 & 33 & 41 & $\mathbf{1 8}$ & $\mathbf{2 1}$ & $\mathbf{7}$ & $\mathbf{2 5}$ & 45 & 46 & 65 \\
2001 & 85 & 29 & 53 & 54 & 38 & 105 & $\mathbf{1 0}$ & $\mathbf{1 1}$ & 142 & $\mathbf{8}$ & 105 & 90 \\
2002 & $\mathbf{2 5}$ & 56 & 48 & 86 & 53 & 27 & 29 & 51 & 49 & 63 & 46 & 43 \\
$\mathbf{2 0 0 3}$ & 85 & $\mathbf{1 4}$ & $\mathbf{8}$ & $\mathbf{1 7}$ & $\mathbf{2 1}$ & $\mathbf{1 3}$ & $\mathbf{2 5}$ & $\mathbf{8}$ & 32 & 107 & 37 & 26 \\
2004 & 93 & 37 & 33 & 78 & 44 & 48 & $\mathbf{1 5}$ & $\mathbf{2 0}$ & 30 & $\mathbf{2 4}$ & 60 & 47 \\
2005 & $\mathbf{1 4}$ & 55 & 28 & 42 & 38 & $\mathbf{2 2}$ & 42 & 65 & 29 & $\mathbf{1 5}$ & $\mathbf{2 4}$ & 142 \\
2006 & 84 & 60 & 60 & 43 & 32 & 34 & $\mathbf{1 4}$ & 55 & $\mathbf{1 1}$ & $\mathbf{1 5}$ & 33 & 43 \\
2007 & 31 & 39 & 52 & $\mathbf{5}$ & 34 & 33 & $\mathbf{1 1}$ & $\mathbf{1 8}$ & 42 & 64 & 62 & 55 \\
\hline
\end{tabular}

Podaci iz tabele 1 jasno ističu klimatski ekstremnu 2003. godinu, u kojoj su tokom 8 mjeseci kritične vrijednosti indeksa suše bile manje od 26 (boldirane oznake), a to su vrijednosti koje karakterišu aridna područja. Treba zapaziti da je u ovoj godini indeks suše bio ispod 25 tokom 7 mjeseci u kontinuitetu (februar-avgust), što je bilo 
prekomjerno i za šume dobrog pufernog kapaciteta. Godina je očigledno bila vrlo stresna za sastojine kitnjaka. Ovome treba dodati da je, pored suše tokom vegetacionog perioda 2003. g., na opštu zdravstvenu sliku šuma hrasta mogla značajno uticati i relativno niska temperatura u prethodnom petomjesečnom periodu zime i ranog proljeća. Minimalna temperatura vazduha bila je od decembra 2002. pa do aprila 2003. g. ispod $0{ }^{\circ} \mathrm{C}$, a u januaru 2003. g. izmjerena je čak $-22,5^{\circ} \mathrm{C}$, što je osnova za tumačenje pojave mrazopucina na deblu kitnjaka, o čemu će kasnije biti riječi. SIWECKI \& UFNALSKI (1998), istražujući uzroke masovnog sušenja hrastova u Poljskoj, zaključuju da ljetna suša kojoj prethodi proljeće sa malo padavina i hladna zima doprinose ovom procesu. Istražujući uzroke masovnog sušenja jele u nas UsčUPLIć i saradnici (2006) takođe ističu značaj klime u ovom procesu.

\subsection{Objekat istraživanja}

Za ova istaživanja izabran je odjel 34/1 G.J. „Motajica” (n.v. 250-350 m). Izbor ovog objekta izvršen je na osnovu ranije zapažene pojave suhovrhosti i sušenja stabala kitnjaka te pojave žute imele. Za mjerenja je izabran odsjek $b$ (G.kl. 1415, $\mathrm{p}=24,80 \mathrm{ha}$ ), sastojina kitnjaka čija je struktura drvne zalihe (prema Uređajnom elaboratu GJ "Motajica“" za period 2003-2012) prezentirana u tabeli 2.

Tabela 2. Debljinska struktura drvne zalihe kitnjaka u odsjeku b, odjela 34/1 GJ „Motajica” (prema Uređajnom elaboratu)

Table 2. Wood stock distribution of the sessile oak in the compartment in 2003

\begin{tabular}{|c|c|c|c|c|c|c|}
\hline \multicolumn{6}{|c|}{ Debljinska klasa $(\mathrm{cm})-$ dbh. classes $(\mathrm{cm})$} & \multirow{2}{*}{$\begin{array}{l}\text { Svega } \\
\text { Total }\end{array}$} \\
\hline $6-10$ & $11-20$ & $21-30$ & $31-50$ & $51-80$ & $81-$ & \\
\hline \multicolumn{7}{|c|}{$\mathrm{m}^{3} / \mathrm{ha}$} \\
\hline- & 2,5 & 13,6 & 198,5 & 73,9 & - & 289,5 \\
\hline
\end{tabular}

\section{METOD RADA - Work method}

Pri prikupljanju podataka na terenu radi utvrđivanja strukture i zdravstvenog stanja hrasta kitnjaka u sastojini, korišten je mrežni model koncentričnih krugova, identičan metodu koji se primjenjuje pri službenoj inventuri šuma. Postavljeni na razdaljini 100 x 100 m, koncentrični krugovi imali su radijuse: 2,$5 ; 4,5 ; 5,5 ; 9,0 ; 15,0$ i 25,0 m. Na najmanjem krugu radijusa 2,5 m mjerena su sva stabla prečnika 5-9,9 cm na prsnoj visini; na krugu radijusa 4,5 m mjerena su sva stabla prečnika 10-19,9 $\mathrm{cm}$ na prsnoj visini; zatim na krugu radijusa 5,5 m sva stabla prečnika $20-29,9 \mathrm{~cm}$ na prsnoj visini; na krugu radijusa 9,0 $\mathrm{m}$ sva stabla prečnika $30-49,9 \mathrm{~cm}$ na prsnoj visini; na krugu radijusa $15,0 \mathrm{~m}$ sva stabla prečnika $50-79,9 \mathrm{~cm}$ na prsnoj visini i najzad na krugu radijusa $25 \mathrm{~m}$ mjerena su sva stabla prečnika iznad $80 \mathrm{~cm}$. U sastojini je ukupno markirano 59 krugova, ali su podaci o taksacionim elementima i zdravstvenom stanju 
stabala sakupljani na $43 \mathrm{kruga}$, tj. onim premjernim krugovima koji su bili na prostoru hrasta kitnjaka. Na ova 43 premjerna kruga zabilježeno je ukupno 179 stabala čija je ukupna drvna zaliha iznosila $514,9 \mathrm{~m}^{3}$. Na slici 1. je topografska karta odjela sa ucrtanom granicom odjela 34/1 i mrežnim modelom postavljenih krugova.

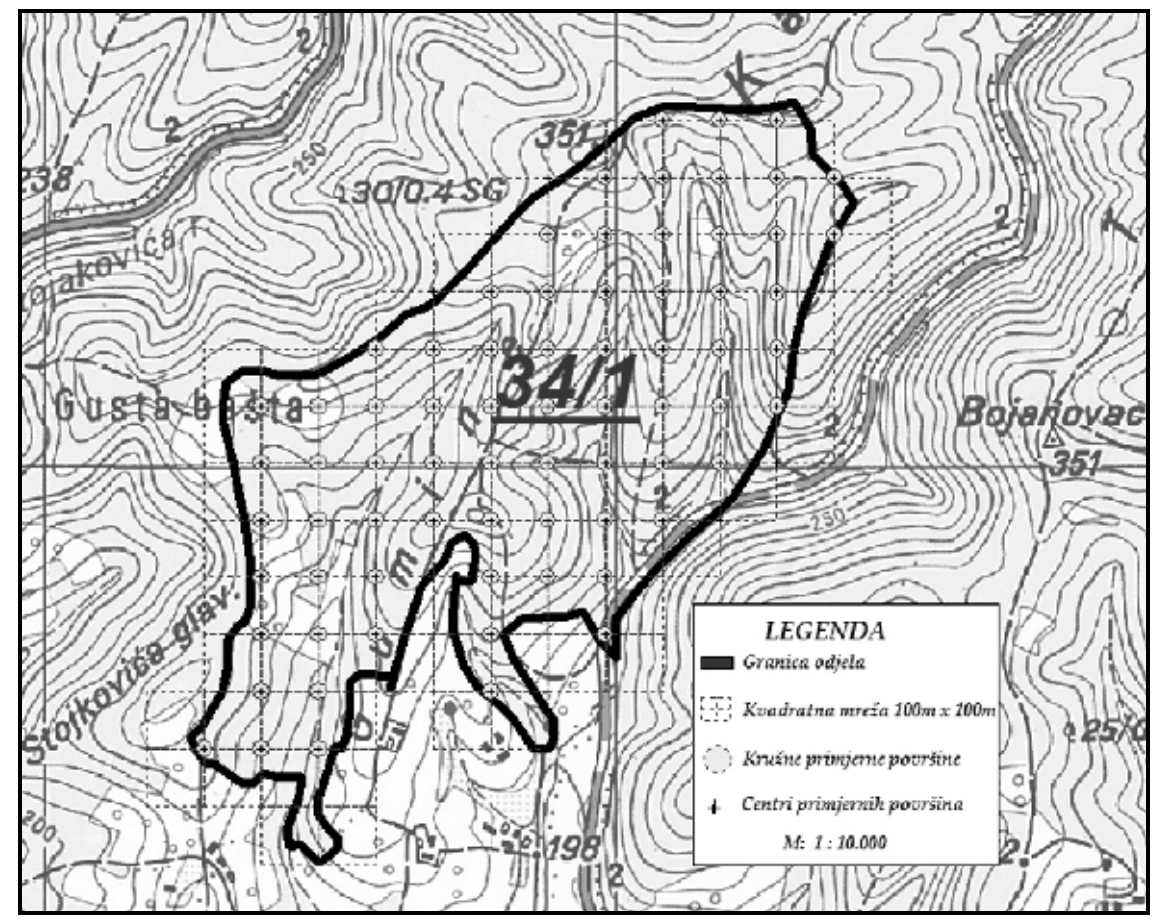

Karta 1. Mreža premjernih krugova u odjelu 34/1 GJ „Motajica”

Map. 1. Experimental network in the sessile oak compartment

\section{REZULTATI ISTRAŽIVANJA - Results}

Podaci o pojavi imele L. europaeus i drugih štetnih agenasa na objektu istraživanja daju se tabelarno i grafički.

\subsection{Pojava imele L. europaeus i intenzitet napada}

Odnos zdravih i imelom zaraženih stabala po debljinskim klasama na premjernim krugovima prezentira se u tabeli 3 (broj stabala) i tabeli 4 (ukupna drvna zaliha), a procentualni odnos zdravih i zaraženih stabala po hektaru u grafikonu 1 (broj stabala) i grafikonu 2 (drvna zaliha). 
Tabela 3. Raspored zdravih i imelom zaraženih stabala kitnjaka po debljinskim klasama na premjernim krugovima

Table 3. Distribution of healthy and infested oak trees

\begin{tabular}{|c|c|c|c|c|c|c|c|}
\hline \multirow{2}{*}{ Kitnjak } & \multicolumn{6}{|c|}{ Debljinska klasa $(\mathrm{cm})-$ dbh. classes $(\mathrm{cm})$} & \multirow{2}{*}{$\begin{array}{l}\text { Svega } \\
\text { Total }\end{array}$} \\
\hline & $20-29,9$ & $30-39,9$ & $40-49,9$ & $50-59,9$ & $60-69,9$ & $70>$ & \\
\hline Zdrava & 15 & 36 & 36 & 38 & 12 & 2 & 139 \\
\hline Zaražena & 2 & 4 & 9 & 15 & 3 & 7 & 40 \\
\hline Svega & 17 & 40 & 45 & 53 & 15 & 9 & 179 \\
\hline $\begin{array}{c}\% \\
\text { zaraženosti }\end{array}$ & 11,8 & 10,0 & 20,0 & 28,3 & 20,0 & 77,8 & 22,3 \\
\hline
\end{tabular}

Tabela 4. Raspored zapremine zdravih i imelom zaraženih stabala kitnjaka po debljinskim klasama na premjernim krugovima

Table 4. Distribution of the wood stock of healthy and infested oak trees

\begin{tabular}{|c|c|c|c|c|c|c|c|}
\hline \multirow{3}{*}{ Kitnjak } & \multicolumn{6}{|c|}{ Debljinska klasa $(\mathrm{cm})-$ dbh. classes $(\mathrm{cm})$} & \multirow{2}{*}{$\begin{array}{l}\text { Svega } \\
\text { Total }\end{array}$} \\
\hline & $20-29,9$ & $30-39,9$ & $40-49,9$ & $50-59,9$ & $60-69,9$ & $70>$ & \\
\hline & \multicolumn{7}{|c|}{$\mathrm{m}^{3}$} \\
\hline Zdrava & 9,6 & 45,5 & 83,5 & 134,0 & 61,2 & 13,9 & 347,7 \\
\hline Zaražena & 1,5 & 6,1 & 19,0 & 55,5 & 15,1 & 70,0 & 167,2 \\
\hline Svega & 11,1 & 51,6 & 102,5 & 189,5 & 76,3 & 83,9 & 514,9 \\
\hline $\begin{array}{c}\% \\
\text { zaraženosti }\end{array}$ & 13,5 & 11,8 & 18,5 & 29,3 & 19,8 & 83,4 & 32,5 \\
\hline
\end{tabular}

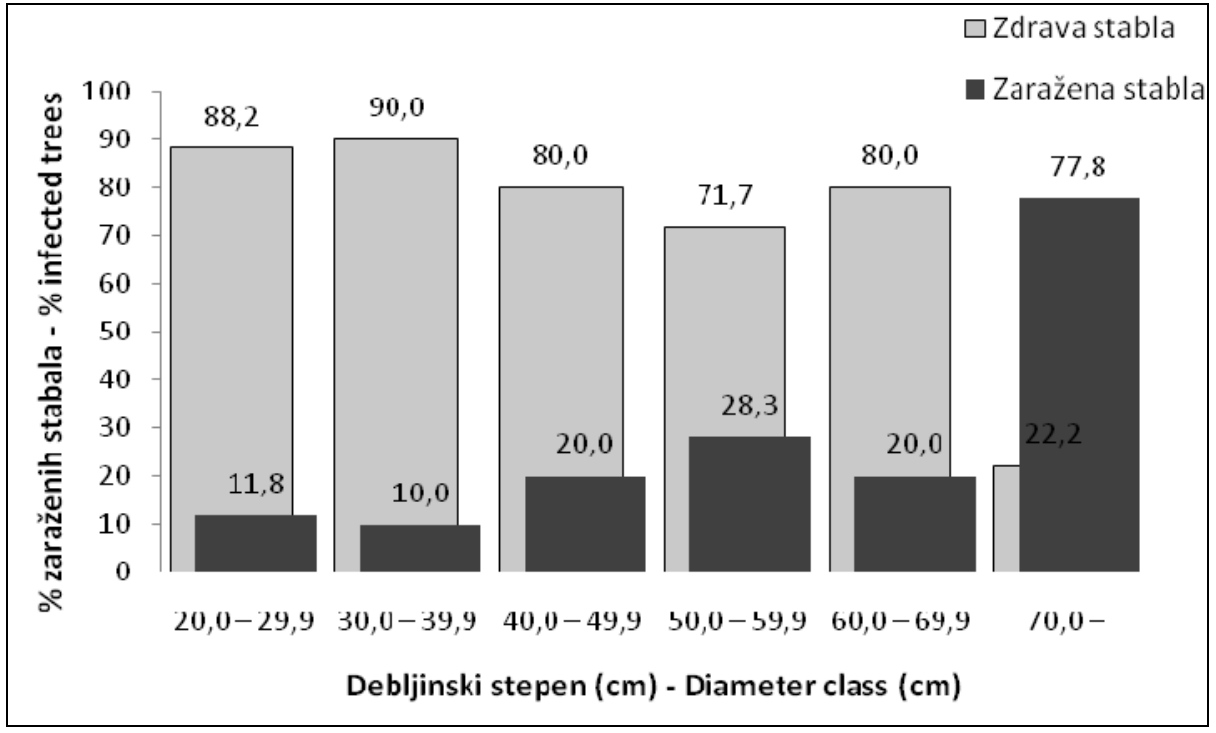

Grafikon 1. Procentualni odnos broja zdravih i zaraženih stabala kitnjaka po debljinskim klasama po hektaru

Fig. 1. Percentage of the healthy and infested oak trees per hectar 


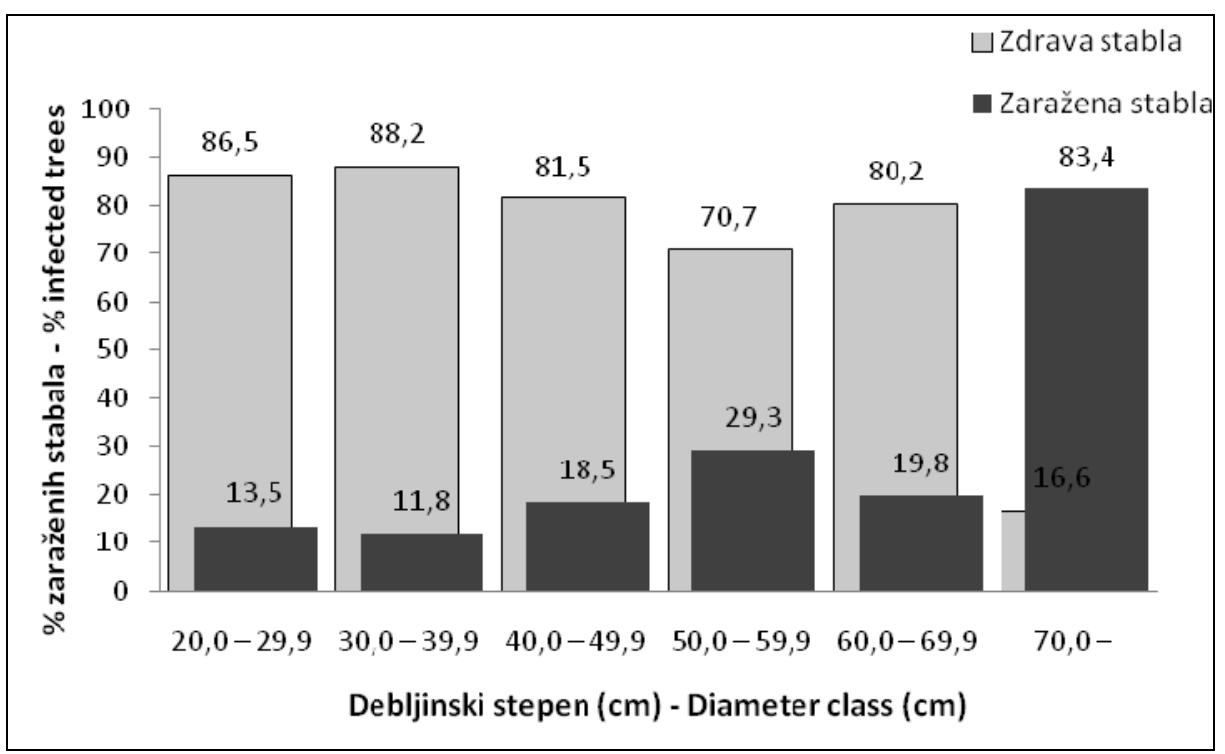

Grafikon 2. Procentualni odnos zapremine $\left(\mathrm{m}^{3}\right)$ zdravih i zaraženih stabala kitnjaka po debljinskim klasama po hektaru

Fig. 2. Percentage of the wood stock of healthy and infested oak trees per hectar

Na 43 kruga u ovom odjelu utvrđeno je 179 stabala kitnjaka, od kojih je 40 $(22,3 \%)$ bilo zaraženo imelom. Kao što se i očekivalo, najmanji broj imelom zaraženih stabala bio je u najtanjoj debljinskoj klasi 20,0-29,9 cm (tabela 3 i grafikon 1).

Intezitet pojave imele (zaraženost stabala imelom) ocjenjivan je na osnovu broja žbunova ovog parazita na stablima na mrežnim premjernim krugovima (tabela 5). Iz ovih podataka vidljivo je da broj žbunova imele na zaraženim stablima varira od 1 do 18 .

Općenito se može reći da je na stablima prečnika do $40 \mathrm{~cm}$ zabilježen manji broj žbunova (1-4 po stablu), dok je na stablima iznad prečnika $40 \mathrm{~cm}$ broj žbunova (uz jedan izuzetak) bio veći od 7, što je i očekivano s obzirom da su deblja stabla u pravilu i starija i bila su duži period pod prijetnjom novih infekcija. 


\section{Neđo Ilić}

Tabela 5. Intenzitet zaraženosti kitnjaka (broj žbunova imele) po debljinskim klasama

Table 5. Intensity of the mistletoe attack per infested tree according to the number of brooms

\begin{tabular}{|c|c|c|c|c|c|c|c|}
\hline \multirow{3}{*}{$\begin{array}{l}\text { Intenzitet } \\
\text { zaraženosti } \\
\quad \text { (broj } \\
\text { žbunova) }\end{array}$} & & & bljins & dasa ( & & & \multirow{3}{*}{ Ukupno } \\
\hline & $\begin{array}{l}20- \\
29,9\end{array}$ & $\begin{array}{l}30- \\
39,9\end{array}$ & $\begin{array}{l}40- \\
49,9\end{array}$ & $\begin{array}{l}50- \\
59,9\end{array}$ & $\begin{array}{l}60- \\
69,9\end{array}$ & $70>$ & \\
\hline & \multicolumn{6}{|c|}{ Broj stabala } & \\
\hline 0 & 15 & 36 & 36 & 38 & 12 & 2 & 139 \\
\hline 1 & 1 & 2 & 0 & 4 & 1 & 0 & 8 \\
\hline 2 & 0 & 1 & 2 & 3 & 0 & 1 & 7 \\
\hline 3 & 0 & 0 & 2 & 0 & 0 & 0 & 2 \\
\hline 4 & 1 & 1 & 1 & 3 & 0 & 0 & 6 \\
\hline 5 & 0 & 0 & 0 & 1 & 0 & 0 & 1 \\
\hline 6 & 0 & 0 & 3 & 1 & 1 & 0 & 5 \\
\hline 7 & 0 & 0 & 0 & 1 & 1 & 1 & 3 \\
\hline 8 & 0 & 0 & 0 & 0 & 0 & 1 & 1 \\
\hline 9 & 0 & 0 & 0 & 0 & 0 & 0 & 0 \\
\hline 10 & 0 & 0 & 0 & 1 & 0 & 1 & 2 \\
\hline 11 & 0 & 0 & 0 & 0 & 0 & 1 & 1 \\
\hline 12 & 0 & 0 & 0 & 0 & 0 & 1 & 1 \\
\hline 13 & 0 & 0 & 0 & 1 & 0 & 0 & 1 \\
\hline 14 & 0 & 0 & 1 & 0 & 0 & 0 & 1 \\
\hline 18 & 0 & 0 & 0 & 0 & 0 & 1 & 1 \\
\hline Svega & 17 & 40 & 45 & 53 & 15 & 9 & 179 \\
\hline $\begin{array}{c}\% \\
\text { zaraženosti }\end{array}$ & 11,8 & 10,0 & 20,0 & 28,3 & 20,0 & 77,8 & 22,3 \\
\hline
\end{tabular}

\subsection{Drugi štetni agensi na kitnjaku}

Pored imele na objektu istraživanja konstatovani su i drugi štetni agensi (mehanička oštećenja, suhovrhost, mrazopucine i trulež drveta) i ovdje se analizira njihova moguća uzročna povezanost (tabele 6 i 7). 
Tabela 6. Međusobni odnos štetnih agenasa na stablima kitnjaka na premjernim krugovima Table 6. Relationship between damaging agents

\begin{tabular}{|c|c|c|c|c|c|}
\hline & Imela & Oštećenja & Trulež & Suhovrhost & Mrazopucine \\
\hline Imela & 40 & 11 & 6 & 9 & 2 \\
\hline Oštećenja & 11 & 46 & 14 & 11 & 13 \\
\hline Trulež & 6 & 14 & 15 & 7 & 2 \\
\hline Suhovrhost & 9 & 11 & 7 & 21 & 2 \\
\hline Mrazopucine & 2 & 13 & 2 & 2 & 15 \\
\hline
\end{tabular}

Tabela 7. Štetni agensi na stabalima kitnjaka na premjernim krugovima po debljinskim klasama Table 7. Distribution of the damaging agents per dbh. classes

\begin{tabular}{|c|c|c|c|c|c|c|}
\hline $\begin{array}{c}\text { Debljinska } \\
\text { klasa } \\
(\mathrm{cm})\end{array}$ & \multicolumn{6}{|c|}{ Broj stabala } \\
\cline { 2 - 7 } & Imela & $\begin{array}{c}\text { Mehanička } \\
\text { oštećenja }\end{array}$ & $\begin{array}{c}\text { Suhovrhost } \\
\text { stabala }\end{array}$ & $\begin{array}{c}\text { Trulež } \\
\text { debla }\end{array}$ & $\begin{array}{c}\text { Mrazopucine } \\
\text { na deblu }\end{array}$ & Svega \\
\hline $20,0-29,9$ & 2 & 4 & 0 & 1 & 2 & 17 \\
\hline $30,0-39,9$ & 4 & 8 & 5 & 2 & 3 & 40 \\
\hline $40,0-49,9$ & 9 & 12 & 8 & 3 & 3 & 45 \\
\hline $50,0-59,9$ & 15 & 16 & 7 & 6 & 5 & 53 \\
\hline $60,0-69,9$ & 3 & 2 & 0 & 1 & 1 & 15 \\
\hline $70,0>$ & 7 & 4 & 1 & 2 & 1 & 9 \\
\hline Ukupno & 40 & 46 & 21 & 15 & 15 & 179 \\
\hline
\end{tabular}

Ako se na osnovu podataka dobijenih na premjernim krugovima izvrši upoređivanje imelom zaraženih stabala i pojava suhovrhosti na tim stablima (tabela 6), što bi moglo biti uzročno povezano, onda je taj odnos 31:9, što znači da je od ukupno 40 imelom zaraženih stabala 9 stabala $(22,5 \%)$ imalo i pojavu sušenja grana u krošnji. $\mathrm{S}$ obzirom da je ukupno bilo 21 stablo sa pojavom suhovrhosti, očigledno je da tu pojavu prouzrokuju i neki drugi faktori okoline (suša, traheomikoze, zagađenje i dr.). Interesantno je upoređivati i broj mehanički oštećenih stabala sa pojavom truleži drveta na tim stablima, što bi takođe moglo biti u uzročnoj vezi. U ovom slučaju utvrđeno je da je od 46 mehanički oštećenih stabala trulež debla utvrđena na 14 stabala $(30,4 \%)$.

Mehanička oštećenja su najvećim dijelom zabilježena u pridanku i u donjem dijelu debla i mogu se pripisati štetama pri sječi i izvozu drveta iz šume. Što se mrazopucina i truleži drveta tiče, ove dvije pojave zabilježene su zajedno samo u dva slučaja (15:2). 


\section{DISKUSIJA - Discussion}

Istraživanja imele L. europaeus u odjelu 34/1 GJ "Motajica" vršena su standardnim dendrometrijskim metodama snimanja taksacionih elemenata. Prikupljeni su podaci o strukturi i zdravstvenom stanju sastojine na 43 premjerna kruga, koja su bila postavljena po mrežnom modelu na razdaljini 100 x $100 \mathrm{~m}$. Na ovaj način ukupno je snimljeno 179 stabala kitnjaka koja su pripadala različitim debljinskim klasama (tabele 3 i 4). Analizom svakog pojedinačnog stabla na premjernim krugovima utvrđen je intenzitet napada imele L. europaeus i evidentirani drugi štetni agensi koji su mogli uticati na stabilnost ovih šuma.

Ova istraživanja su potvrdila mišljenja drugih istraživača da je sušenje hrasta kompleksna pojava i da se ne može pripisivati bilo kojem pojedinačnom uzročniku (ETTINGER, 1889; ŠKORIĆ, 1926; ELIÁŠ, 1988; SIWECKI \& UFNALSKI, 1998). Ističe se da je promjena klime stresni faktor koji destabilizira šume hrasta i predisponira ih napadu biotičkih štetnih agenasa (SIWECKI \& UFNALSKI, 1998; STEINER, 1998 i dr.). SIWECKI \& UFNALSKI (1998) napominju da su klimatski nepovoljne naročito one godine u kojim sušnom periodu prethodi hladna zima i proljeće sa malo padavina. Sličan zaključak se može donijeti i na osnovu ovih istraživanja.

Analizom klimatskih uslova za područje Motajice (podaci meteorološke stanice u Srpcu) utvrđeno je da je indeks suše u 2003. godini tokom sedam uzastopnih mjeseci (uključujući i vegetacioni period) bio ispod kritičnog praga vrijednosti 25 (vrijednost koja obilježava aridni klimat). Dodatno, u zimskom periodu koji je prethodio suši zabilježene su temperature ispod $0{ }^{\circ} \mathrm{C}$ tokom pet mjeseci (decembar 2002. do aprila 2003.), a u januaru 2003. minimalna temperatura je pala čak na $-22,5$ ${ }^{\circ} \mathrm{C}$. Nema sumnje da su ovakve klimatske prilike uticale na kondiciju stabala u sastojini. Nažalost, monitoring u našim šumama nije razvijen tako da nedostaju podaci o mogućim štetama od niskih temperatura u ovom periodu, što bi svakako bilo vrlo značajno za potpunije razumijevanje drugih pojava u sastojini. UsčuPLIć i saradnici (2007), istražujući uzroke masovnog propadanja jele $\mathrm{u} \mathrm{BiH}$, takođe su istakli da je $\mathrm{u}$ sušnoj 2003. godini iniciran proces sušenja jele u nas.

Imela na kitnjaku utvrđena je na 40 stabala $(22,3 \%)$ od 179 , koliko je analizirano na premjernim krugovima (tabela 3). Njeno procentualno učešće bilo je najmanje u debljinskim klasama 20-20.9 cm i 30-30,9 cm (11,8\% i 10,0\%), a najveće u debljinskoj klasi iznad $70 \mathrm{~cm}(77,8 \%)$, što se objašnjava činjenicom da su deblja stabla u pravilu i starija i da su bila duži period života pod prijetnjom novih infekcija. Što se tiče intenziteta napada imele, mjereno brojem žbunova parazita na zaraženim stablima, općenito se može reći da on takođe raste u višim debljinskim klasama.

Od ukupno 40 imelom zaraženih stabala kitnjaka, 9 stabala (22,5\%) je imalo i pojavu sušenja grana u krošnji, što daje osnov za zaključivanje da i imela doprinosi procesu sušenja grana. S obzirom da je ukupno bilo 21 stablo sa pojavom suhovrhosti, očigledno je da tu pojavu prouzrokuju i neki drugi faktori okoline (suša, traheomikoze, zagađenje i dr.).

Upoređujući broj mehanički oštećenih stabala sa pojavom truleži drveta na tim stablima, kao mogućoj uzročnoj povezanosti, utvrđeno je da je od 46 mehanički 
oštećenih stabala trulež debla utvrđena u 14 slučajeva (30,4\%). Mehanička oštećenja su najvećim dijelom zabilježena u pridanku i u donjem dijelu debla i mogu se dovoditi u vezu sa štetama pri sječi i izvozu drveta iz šume.

\section{ZAKLJUČCI - Conclusion}

Hrast kitnjak (Quercus petraea) se sve intenzivnije suši na području Motajice. Žuta imela (Loranthus europaeus) na kitnjaku, koja je jedan od štetnih agenasa, utvrđena je na premjernim krugovima na Motajici (odjel 34/1 GJ „Motajica“) na 40 od 179 analiziranih stabala (22,3 \%). Imelom zaraženih stabala bilo je u svim debljinskim klasama (tabela 3), ali je njihova procentualna zastupljenost rasla sa prsnim prečnikom stabala. Najmanje zaraženih stabala bilo je u debljinskoj klasi 20-29,9 cm (11,8\% stabala, odnosno $13,5 \%$ drvne zalihe) i debljinskoj klasi 30-39,9 cm (10\% stabala, odnosno 11,8\% drvne zalihe), a najviše u debljinskoj klasi preko $70 \mathrm{~cm}(77,8 \%$ stabala, odnosno $83,4 \%$ drvne zalihe). Identičan je zaključak i u pogledu intenziteta napada imele mjeren brojem žbunova ovog parazita na zaraženim stablima, što znači da je intenzitet napada veći na debljim stablima.

Klimatski faktori imali su važnu ulogu na opšte zdravstveno stanje šuma na Motajici, jer je ekstremno sušna 2003. godina, kada je indeks suše, računat prema De Martonne-ovoj formuli, bio kontinuirano tokom 7 mjeseci ispod 25 - vrijednosti koja je karakteristična za aridna područja (tabela 1). Dodatno, zima koja je prethodila ovom sušnom periodu imala je u toku 5 mjeseci temperature ispod $0{ }^{\circ} \mathrm{C}$, a u januaru 2003. je zabilježena čak $-22,5{ }^{\circ} \mathrm{C}$. Nema podataka o mogućim štetama od mraza iz tog perioda. Borba protiv žute imele na hrastu, čije širenje može dodatno da ugrozi stabilnost ovih šuma, treba da bude sistemski i sistematski vođena, što podrazumijeva monitoring njene pojave $\mathrm{i}$ širenja, pravovremenu primjenu mehaničkih mjera (sanitarna sječa zaraženih stabala) i izbor optimalnog sistema gazdovanja. Odlaganje sječe zaraženih stabala do njihovog potpunog sušenja je nerazumno i nestručno, jer se na ovaj način podstiče a ne ublažava narušavanje stabilnosti šuma hrasta.

\section{Literatura - References}

ELIÁŠ, P. (1988): Quantitative eocological analysis of a mistletoe (Loranthus europaeus Jacq.) population in an oak- hornbeam forest: discrete unit approach. Institute of Experimental Biology and Ecology of Centre of Biological and Ecological Sciences of the Slovak Academy of Sciences, Vol. 7, No. 1, pp. 3-17, Bratislava.

ETTINGER, J., 1889: Upliv imele (liepak, Loranthus europeus) na prirast drva. Šumarski list XIII.

IDŽoJtić, M., PernaR, R., LisjaK, Z., Zdelar H., \& ANČIĆ, M. (2005): Domaćini žute imele (Loranthus europaeus Jacq.) i intenzitet zaraze na području Uprave šuma podružnice Požega. Šum. list 1-2: 3-17. 
KRüssmann, G. (1977): Handbuch der Laubgehölze. Band II-III. Verlag Paul Parey, Berlin und Hamburg.

Matić, V., Drinić, P., Stefanović, V., ĆIrić, M., Beus, V., Bozalo, G., Golić, S., Hamzić, U., Marković, LJ., Petrović, M., Subotić, M., Talović, N., Travar, J. (1971): Stanje šuma u Bosni i Hercegovini (prema Inventuri šuma na velikim površinama u 19641968). Šumarski fakultet i Institut za šumarstvo u Sarajevu, Posebno izdanje br. 7.

SIWECKI, R. \& UFNALSKI, K. (1998): Review of oak stand decline with special reference to the role of drought in Poland.- Eur. J. For. Path. 28, pp. 99-112.

ŠKoRIĆ, V. (1926): Uzroci sušenja naših hrastovih šuma.- Glasnik za šumske pokuse 1, pp. 1-15, Zagreb.

Šumskoprivredna osnova ŠPP Srbačko, sa važnošću od 1.I.2003 do 31.XII.2012. god. JPŠ „Srpske šume“ RS, IRPC, Banja Luka.

TREŠTIĆ, T., DAUTBAŠIĆ, M., MuJEZINOVIĆ, O. (2006): Uticaj hrastove imele (Loranthus europaeus Jacq.) na stabilnost sastojina hrasta kitnjaka.- Radovi Šumarskog fakulteta Univerziteta u Sarajevu, No 1.

Usčuplić, M., Dautbašıć, M., Treštić, T., Selman, E., Mujezinović, O., Nišıć, T. I JoKANOVIĆ, B: (2007): Bolesti i štetnici obične jele (Abies alba Mill.) u Bosni i Hercegovini. Društvo za zaštitu bilja u Bosni i Hercegovini.

\section{SUMMARY - Sažetak}

Decline of the sessile oak [Quercus petraea (Mattuschka) Lieblein] in Bosnia and Herzegovina is increasing recent years. Investigation carried out in a sessile oak stand on the mountain Motajica (northern Bosnia) shows that both environmental factors (e.g. climatic changes, mismanagement etc.) and attack of the mistletoe Loranthus europaeus are responsible for this process.

Regarding climatic factor it is worth to mention that the year 2003 was extremely dry (Table 1). This very year drought index for this region was below 26 during eight months, and even below 25 during seven months continually (February-August). In addition, the minimum air temperature during previous winter (December 2002 to April 2003) was below $0{ }^{\circ} \mathrm{C}$ and coming down even to $-22,5{ }^{\circ} \mathrm{C}$ in January 2003.

The mistletoe was present in all tree dbh. classes, but its occurrence increases with the tree diameter. Number of the infested trees over $70 \mathrm{~cm}$ was $77,8 \%$ (Table 3 ). The intensity of the attack measured according to the number of the mistletoe brooms per infested tree depends also on the dbh. classes (Table 5).

It is concluded that lack of a proper forest management was among the factors responsible for the mistletoe spread. 